Schulich School of Law, Dalhousie University

Schulich Law Scholars

Research Papers, Working Papers, Conference

Papers

Faculty Scholarship

7-22-2009

\title{
Proprietary Interests and Collaboration in Stem Cell Science: Avoiding Anticommons, Countering Canalyzation
}

Matthew Herder

Dalhousie University, matthew.herder@dal.ca

Follow this and additional works at: https://digitalcommons.schulichlaw.dal.ca/working_papers

Part of the Health Law and Policy Commons, and the Intellectual Property Law Commons

\section{Recommended Citation}

Matthew Herder, "Proprietary Interests and Collaboration in Stem Cell Science: Avoiding Anticommons, Countering Canalyzation (2009) Dalhousie University Schulich School of Law Working Paper No 34.

This Working Paper is brought to you for free and open access by the Faculty Scholarship at Schulich Law Scholars. It has been accepted for inclusion in Research Papers, Working Papers, Conference Papers by an authorized administrator of Schulich Law Scholars. For more information, please contact hannah.steeves@dal.ca. 


\title{
Chapter 21 \\ Proprietary Interests and Collaboration in Stem Cell Science: Avoiding Anticommons, Countering Canalyzation*
}

\author{
Matthew Herder
}

\begin{abstract}
In this chapter I explore how proprietary interests and commercialization norms can impede collaboration in stem cell science. I begin by outlining three layers of property in stem cell science-stem cell data, stem cell materials, and stem cell patenting - and explain how they are intertwined in practice. I then present two stem cell research initiatives, the Cancer Stem Cell Consortium (CSCC) and Stem Cells for Safer Medicines (SC4SM). Using two conceptual frames, the "tragedy of the anticommons" and "patent canalyzation," I analyze the extent to which the CSCC and SC4SM appear to address proprietary or commercialization-related impediments to collaboration. Whereas the anticommons frame, and empirical methodologies it has spawned to date, tends to capture costs imposed upon the scientific fields as a whole, patent canalyzation focuses on the individual scientist, hypothesizing that patenting and other commercialization behaviours may (re) constitute the scientific self. The chapter concludes by highlighting three intellectual property-related best practices intended to facilitate collaboration in stem cell science.
\end{abstract}

Keywords Stem cells $\bullet$ Patents $\bullet$ Commercialization $\bullet$ Anticommons $\bullet$ Data sharing

\footnotetext{
* An earlier version of this paper (entitled "Two Models of Commercializing Stem Cell Science: Creating Conditions for Collaboration?") was prepared on behalf of Health Canada, Contract Ref. No. 4500199156.

M. Herder $(\square)$

Department of Bioethics, Dalhousie University, 5849 University

Avenue, Halifax, Nova Scotia, B3H 4H7, Canada

e-mail: Matthew.Herder@Dal.Ca
} 


\subsection{Introduction}

All collaboration is complicated. The decision to do so is informed by two principal considerations: how easy it is to collaborate, and how attractive it is to do so. The trouble is that those considerations are, in turn, contingent upon a number of other things that would-be collaborators may have little control over, imperfect knowledge about, or subject to the influence of. Take any field of scientific inquiry today: researchers must abide by ethical requirements, participate in the commercialization of their work, and compete to prove their expertise. Each is relevant to any question of scientific collaboration.

Recent forecasts for collaboration in stem cell science - the field that I will explore here - have leaned toward the negative. Some assert that inconsistent regulatory frameworks from one jurisdiction to the next make cross-border collaboration difficult [1]. According to David Winickoff, Krishanu Saha and Gregory Graff, the problem may be even more intractable. In their view, collaboration suffers because actors have failed to tackle, in an integrated fashion, the full range of issues - from the ethical, to the technical and proprietary - raised by stem cell science. As a result, Winickoff, Saha, and Graff conclude that this "exploding field...is characterized by a lack of any deeply collaborative architecture" [2, p. 57].

I agree with Winickoff, Saha and Graff's contention that an integrated approach is needed. However, I want to investigate further into the proprietary dimension of stem cell science. In an age where commercializing publicly funded research is considered a legitimate goal, many have begun to ask whether that process, and the proprietary posturing it tends to command, is undercutting collaboration - that is, collaboration that would occur despite the added constraints of complying with ethical standards (which are well justified) and norms of scientific competition. Much of the focus at this point is upon figuring out if commercializing research actually poses a problem, and if so, exactly what the problem is. Is patenting bad in and of itself? Or is it more a matter of how patent rights are exercised or licensed? Are difficulties in obtaining biological materials a bigger concern? Maybe various challenges associated with experimental data - from storing it, to sharing and verifying it - that is neither published nor patented deserves more attention? The problem is tough to define. Yet architects of large-scale research initiatives are making decisions about these issues in real time while others still are beginning to ask whether those in a position to effect change are doing enough. Meanwhile, the science evolves.

Something, in my view, may have been missed in the debate over patenting in biomedical research - a novel type of cost that I term "patent canalyzation," which speaks directly to patterns of scientific collaboration. To explain how this potential cost of commercialization differs from the "anticommons," the dominant conceptual frame at the moment, I will analyze two nascent research initiatives - "Stem Cells for Safer Medicines" based in the United Kingdom, and the cross-border Canada-California "Cancer Stem Cell Consortium" - which escaped Winickoff, Saha and Graff's survey. Before examining those two initiatives in detail, it is first necessary to provide some additional background about how different proprietary elements of stem cell science are intertwined. 


\subsection{Property Layers}

Property rights, whether attaching to intellectual or more tangible objects, have been generating a growing amount of controversy in stem cell science. The bulk of the criticism relates to the sharing of stem cell materials, particularly, human embryonic stem cell (hESC) lines, and the entity, the Wisconsin Alumni Research Foundation (WARF), accused of inadequately doing so. WARF's (in)actions have attracted the most attention because it holds the patent rights over the process of the deriving of hESCs from human embryos, ${ }^{1}$ a technique pioneered by University of Wisconsin scientists James Thomson during the 1990s [3]. That many in the research community have condemned the way WARF has handled the distribution of hESC lines dovetails with recent surveys where researchers in the life sciences generally have expressed greater frustration with material transfer agreements (MTAs) than patents per se [4-6]. However, it is important to understand that the two proprietary means of maintaining control and extracting rents from users of hESCs - patent rights and the MTAs that frequently accompany the exchange of biological materials, including hESCs - are mutually reinforcing [7, 8]. Patent rights give WARF the power to police those who would otherwise try to create hESCs on their own. MTAs preserve WARF's interest in any future technologies developed using the hESCs that WARF provides to others.

WARF's strategy is not exceptional. Coupling patent rights and MTAs is a common strategy among universities today [5]. Given the potential of hESCs to remedy human disease, however, the normal course is arguably not good enough. Learning from these experiences with hESC patents and materials exchange is in any event critical, especially as promising new directions of inquiry within stem cell science emerge, such as "induced pluripotent stem (iPS) cells" - a field that WARF also appears poised to control. ${ }^{2}$ Equally integral to progress in stem cell science is access to stem cell "data." Data is essentially information that is not necessarily eligible for patent (or copyright) protection, ${ }^{3}$ but that is critical to scientists' ability

\footnotetext{
${ }^{1}$ To my knowledge, these patent rights have thus far been granted in the USA only.

${ }^{2}$ In November 2007, two groups, one led by James Thomson at the University of Wisconsin and the other led by Shinya Yamanaka of Kyoto University in Japan, reported experiments in which they were able to genetically reprogram human adult cells into hESC-like, pluripotent stem cells (that is, these so-called "iPS cells" were similar to hESCs in morphology, proliferation, cell surface markers, pluripotent cell-specific gene expression, and telomerase activity) [9, 10]. While there are differences between the techniques and results of the Thomson and Yamanaka groups, the patent application filed by WARF on behalf of Thomson entitled "Somatic Cell Reprogramming" (US Patent Application No. 12/053,440 [with priority date 23 March 2007]) may encompass Yamanaka's work and thus assume priority. Yamanaka has already secured a Japanese patent on iPS cells and designated the USA, among other countries, for the purpose of his application under the Patent Cooperation Treaty (PCT/JP2006/324881). However, Yamanaka apparently failed to include an English translation with his application, allowing Thomson's application to assume priority [11-13].

${ }^{3}$ In Europe, data or information can be protected as part of a database. This type of protection does not exist elsewhere, however.
} 
to replicate the findings of others and work with well-characterized stem cell lines. The remainder of this background section thus explains these three overlapping elements - stem cell data, materials, and patents - in greater, but far from comprehensive, detail.

\subsubsection{Stem Cell Data}

Knowing the precise characteristics of a given stem cell population is fundamental to a researcher's ability to understand, utilize, and draw conclusions from any experiments involving those stem cells [14]. The researcher must not only have information about stem cell genomes, gene, and protein expression, but also information about the culture history of those cells, including "the particular growth factors that have been added to the media, the substrate of the cell culture," whether any "implantable materials" or "genetic engineering vectors" were used, and the "duration of such events" [2, pp. 69-70].

Several groups and institutional actors have thus called for or sought to facilitate enhanced stem cell data sharing. For example, an international and interdisciplinary team known as the "Hinxton Group" issued a consensus statement in 2006 in which it encouraged researchers to "make cell lines and data...publicly available" [15]. The International Society for Stem Cell Research (ISSCR) has sought to advance the same goal through its journal Cell Stem Cell by making data (and materials) sharing a condition of publication [16]. Whereas the established registries or stem cell banks in the USA and the UK have failed to compile more than a list of the lines they hold, two more recent projects - the "International Stem Cell Forum" and the "European hESC Registry" - appear to be taking data collection for the purpose of stem cell characterization much more seriously [2, pp. 86-7].

Yet, to date, this invaluable data is seldom published or packaged together with samples of stem cells sent out by the various banks and registries that exist. The reasons are complex: there is a long history of poor data sharing in scientific circles for purely competitive reasons [17]. The data issue also intersects with disincentives associated with sharing stem cell materials and obstacles engendered by certain patent licensing practices (discussed below). In short, though, those in a position to leverage greater data sharing have neglected to do so. A lot of journals have not been proactive. The policy espoused by Cell Stem Cell appears to be the exception, not the rule, and a hard rule to enforce at that [2, pp. 61-2]. Moreover, research funding bodies which, apart from legislatures, have the greatest power to effect change, have essentially avoided the issue. Most notably, perhaps, the California Institute for Regenerative Medicine ("CIRM"), a body created by popular vote in 2004 with $\$ 10$ billion at its disposal, has so far failed to translate its broad endorsement of data sharing into concrete expectations that bind the recipients of CIRM grants [18]. 


\subsubsection{Stem Cell Materials}

That various stem cell registries and banks exist should, in principle, facilitate materials exchange relative to a world where researchers and institutions are left to negotiate the terms and conditions of material transfer on a case-by-case basis. However, the creation of an electronic registry or, more ideally, an actual bank of stem cell lines, will not by itself preclude materials-sharing problems from arising. It is simply a first step toward mitigating them and is likely to be ineffective without simultaneously tackling the intellectual property dimension of those materials. For example, WARF's participation made the creation of the US National Institutes of Health (NIH) "Human Embryonic Stem Cell Registry" possible, in principle, enhancing access to stem cell lines derived in accordance with the (now repealed) criteria established by former US President Bush [19, 20]. Even so, well after the creation of the registry, WARF was seen by many as imposing undue constraints upon the distribution of hESC lines by virtue of its patent rights and the licensing strategies it chose to pursue $[2,7]$.

In a positive move, WARF relaxed its stated policy positions in early 2007. Specifically, WARF (1) removed the stipulation embedded in the MTAs accompanying hESC samples sent to academic institutions that private sector sponsors of such research be required to negotiate a separate commercial license with WARF; (2) allowed inter-laboratory transfer of non-WARF hESC lines without WARF's permission; and (3) retracted its assertion that it was entitled to some portion of CIRM grants [21]. Moreover, the recent removal of former President Bush's restrictions around funding hESC research - restrictions that effectively strengthened WARF's control over the field by precluding the creation of new hESC lines with federal funds - may diversify the available sources of hESC materials.

However, several materials-related stumbling blocks remain. First, WARF's change in position "does nothing to change the fact that any entity seeking to commercialize hESC technology [in the USA] will have to negotiate a commercialized license from WARF" [2, p. 73]. To date, WARF has only entered into a handful of commercial licenses, and the broad set of exclusive rights that it has already granted to Geron Corporation, which funded Thomson's pioneering hESC work, may hamper any future negotiations [7]. Second, it is unclear what WARF has taken from its experience with hESC lines. Assuming it becomes the dominant patentholder in respect to iPS cells and methods of manufacturing the same, there is a risk that WARF will seek to maintain a similar level of control, not only in the USA but also abroad, because iPS cells would not seem to trigger the same bars to patentability in Europe as hESCs [22]. Third, new avenues of stem cell research, most notably for my purposes in this chapter, research into "cancer stem cells" [23], require large-scale repositories of other kinds of biological materials (e.g., biopsied tumor samples). Unlike hESCs, those biological materials may not be in short supply. But optimizing them for research use nevertheless requires specialized facilities, highly qualified personnel, and complex information management systems, thus carrying a host of other costs. 


\subsubsection{Stem Cell Patents}

As foreshadowed above, WARF's patent rights and the manner in which it has purported to exercise them is the dominant theme in the discussion around patenting stem cell technologies. That WARF might soon lay claim to foundational methods of making iPS cells as well as the cells themselves is likely a growing concern. However, as Karl Bergman and Gregory Graff have shown in depth, the global stem cell patent landscape is in fact radically more complex. Although the number of applications has declined in all three primary filing sites since 2001-2002, patenting of stem cell lines, stem cell preparations and growth factors remains "intense," with ownership "fragmented across multiple organizations" [24, pp. 421-422].

Several questions follow from this. The first set of questions - the focus of most of the literature to date - concerns whether and to what extent this proliferation of patent rights is slowing progress in stem cell science. Winickoff, Saha and Graff, for instance, warn that "the complex set of technologies... necessary to control the early stages of differentiation... will not have many alternatives," thus generating opportunities for patent owners to hold up and/or add a toll to the research and development process [2, p. 75]. In essence, the concern is that the transaction costs associated with getting access to the necessary stem cell data, materials, and patented technology will, sooner or later, trump scientific progress. This is the stuff of an "anticommons tragedy" - too much property begets underuse of a resource [25].

A second set of as-yet unrecognized questions asks not whether an overabundance of (ambiguous) property rights might impede the collaboration that we would like to see, but rather whether the fact of having a proprietary interest might lead those doing the science to collaborate less in the first place. If that proves to be true, the consequences for stem cell science may not simply be a loss of efficiency, but diminished quality. I term this second type of cost potentially associated with pursuing commercialization - perhaps only too soon or too much, not by definition - "patent canalyzation." The next section of the chapter explains the concept in greater depth, contrasting it with the anticommons metaphor. As I will explain further below, it is critical to note that the evidentiary basis for patent canalyzation, like the anticommons, is minimal at present. Nevertheless, managing both risks makes sense.

\subsection{Crowding Out Collaboration? The Tragedy of the Anticommons Versus Patent Canalyzation}

Concerns about patenting in the upstream research space have been voiced for some time. Skepticism climaxed around one captivating hypothesis, "the tragedy of the anticommons" [25]. In essence, an anticommons can emerge when property rights 
are many and messy. Michael Heller coined the concept after observing merchant kiosks thrive outside scores of empty stores on the streets of post-socialist Russia [26]. That the stores had been newly carved up by a variety of property rights was to blame. With the help of Rebecca Eisenberg, Heller cautioned that the same tragedy might befall biomedical research. The authors warned that the abundance of fragmented, overlapping, and ambiguous patent rights in the upstream research space "may lead paradoxically to fewer useful products for improving human health" [25, p. 701].

Evidence of such a tragedy has, however, been less than forthcoming. Using opinion surveys, John Walsh and colleagues have shown that academic researchers working in the fields of genomics and proteomics very rarely consider patents to be an impediment to choosing or pursuing a particular research project. Conversely, MTAs represent a bigger source of concern $[4,5]$. In a study of stem cell scientists specifically using similar methodology, Timothy Caulfield et al. found essentially the same thing: minimal evidence of researchers' experiencing patent-related problems [6].

What explains these findings, given the abundance of patent rights in both fields? The answer is surprisingly straightforward: in contrast to MTAs, which researchers tend to be highly aware of (because the costs of making materials in-house are often considered too high), researchers tend to have no immediate awareness of patent rights [5]. The situation may change in the future if either universities' fear of liability or patent-holders' willingness to test it increases [27]. For the moment, however, academic scientists largely ignore the possibility that they are potentially engaging in patent infringement. Thus, the absence of an anticommons.

The only evidence we have of an anticommons effect is indirect. Using a novel type of citation analysis, Fiona Murray and colleagues have shown that overall knowledge flows (measured by citations to a published article) decrease after a patent pertaining to the knowledge embodied in that same article is issued [28, 29]. The most recent and broadest study in this series, authored by Kenneth Huang and Fiona Murray and encompassing 1,279 human gene "patent-paper pairs," showed that citations to the paper in each pair decreased by $5 \%$ post-patent grant - an effect that was exacerbated by an increase in patent thicket density, patent strength, and whether or not the genetic sequence in question was known to relate to some form of human cancer [29]. Even assuming these figures are something to worry about it, they remain puzzling. If most researchers are not cognizant of patent rights, why is a decrease in citations to published knowledge observed [30]? The findings of Murray and colleagues therefore merit cautious interpretation [27].

This is where patent canalyzation theory can step in and help fill the analytical void. The term is inspired by the work of Conrad Hal Waddington. In the late 1930s and early 1940s, Waddington began using the term "canalyzation" in connection with his notion of an "epigenetic landscape" - a metaphor that Waddington invoked to illustrate the deficiencies of biological discourse at the time. The terms "genotype" and "phenotype" only captured "differences between whole organisms... [and were in Waddington's opinion] not adequate or appropriate for the consideration of differences within a single organism" [31, p. 156]. 
Following a series of experiments with amphibian embryos, Waddington proposed the concept of canalyzation to capture his inference that genetically mediated pathways dictate cell fate. Absent some sort of external "perturbation," such fate could not be altered. It was entrenched or, as Waddington put it, canalyzed.

That basic scientific idea still holds some explanatory power, ${ }^{4}$ and I have chosen to steal from Waddington's powerful notion of canalyzation in order to frame a novel cost potentially associated with patenting early stage research. As with canalyzation in the biological sense, the idea with patent canalyzation is that a researcher becomes increasingly locked into a particular line of scientific inquiry over time. The researcher can diverge from this path but it becomes progressively harder or, again, using Waddington's language, requires an increasingly "significant perturbation," to do so until the project's fate is determined. This could apply regardless of whether a researcher condones commercialization of her work. Acceptance of a government grant carries an obligation to see the research project through. My theory, however, is that the process of commercialization (from disclosure of the invention to filing a provisional patent application, executing one or more licensing agreements, prosecuting the patent until it is issued, and attempting to generate new sources of revenue), whether realized in whole or in part, will exacerbate the level of canalyzation that we would otherwise see - assuming the researcher has some real-time awareness of the commercialization process. Researchers may be generally ignorant of patents held by others but they are presumably more familiar with commercialization activity tied to patents of their own.

This notion of patent canalyzation obviously borrows from another longstanding concept: path dependence. With the exception of Paul David's work regarding how one sub-optimal technology (the "QWERTY" letter arrangement along the keyboard's top row) became the industry standard [33], I am unaware of any scholarly work that invokes the concept of path dependence specifically to help explain observed quality tradeoffs in research or technology development. I therefore prefer to use this new term of patent canalyzation to underscore its focus upon the quality costs potentially associated with patenting, and to contrast those costs with the sort of transaction costs that anticommons analyses typically draw attention to.

Under anticommons analysis the impact, if any, of patenting upon other users of the knowledge that has been appropriated is the principal focus. In contrast, patent canalyzation is trained on the individual scientist(s) credited with the invention and tries to discern the impact of participating in commercialization pre- and post-patent grant. Does, for instance, the commercialization process lead researchers to become increasingly insular (observable, for instance, by citing

\footnotetext{
${ }^{4}$ For example, Shinya Yamanaka's elegant experiment demonstrating how to induce adult stem cells into a pluripotent state through the manipulation of the cells' transcription factors quickly calls to mind Waddington's epigenetic landscape and notion of canalyzation - yet Yamanaka's work was published in 2006. Yamanaka has himself subsequently adapted Waddington's epigenetic landscape in order to explicate different models of iPS cell generation [32].
} 
others less, or citing themselves or members of their own close-knit group more) in the course of their research? If so, what tradeoffs does that carry? In the context of molecular biology, for example, does it account for why so many of the studies done to date have been "underpowered," that is, involve few patient samples and extend only short periods of time [34]? We know that current levels of experimental replication are exceedingly low insofar as "biomarker"-disease associations are concerned [35], and that many biomarker-disease associations have subsequently been shown to be spurious [34]. Does participation in commercialization make scientists less likely to experimentally validate or refute the work of their peers? If so, patent canalyzation may explain why most known biomarkers of human disease, genetic or otherwise, appear to be of questionable clinical validity [36].

Each of these tradeoffs is theoretical at present. The concept of patent canalyzation is only introduced here, not proven. And, directly contrary to what the preceding paragraph suggests, at least one group of scholars has suggested the exact opposite - that improving the clinical validity of biomarkers requires a further, although refined, embrace of patent rights [36]. My current research is aimed at empirically testing whether patent canalyzation, in fact, occurs. However, a few disparate pieces of evidence already exist that suggest that patent canalyzation may be real.

First, Jerry and Marie Thursby have found that researchers' publications drop in years when an invention disclosure is made [37]. Second, Toby Stuart and Waverly Ding have shown that coauthor networks typically contract after an academic scientist transitions to a more openly entrepreneurial environment, either by founding a start-up company or becoming a member of a firm's board of directors [38]. Third, Carlos Cosell and Ajay Agarwal have shown that the overall breadth of knowledge flows associated with university patents has diminished by more than $50 \%$ since the early 1980s [39]. Fourth, and finally, Tania Bubela and colleagues have demonstrated that although the stem cell scientists surveyed by Caulfield and colleagues may not report any problems relating to patents, there was a direct correlation between the number of patents a researcher held and how collaborative she was. Specifically, more patents equaled fewer coauthoring relationships [40].

Thus, as I have argued elsewhere, just because researchers are ignoring patents held by others, thereby avoiding the various transaction costs that paying attention to those patents would entail in the immediate to short term, does not mean that such a state of being is cost free (quite apart from the costs associated with patent prosecution, licensing, and any ensuing litigation) [41]. On the contrary, this more insular state of being may carry other costs - patent canalyzation costs - that could ultimately undermine the quality of one's own scientific research and the quality of the field as a whole.

The remainder of the chapter examines how well two large-scale stem cell research initiatives - the Cancer Stem Cell Consortium ("CSCC") and Stem Cells for Safer Medicines ("SC4SM") - guard against both anticommons and patent canalyzation concerns. 


\subsection{Two Models of Stem Cell Commercialization}

The CSCC and SC4SM initiatives differ in several respects. The origins of the former are bottom-up in that the CSCC was conceived by members of Canada and California's stem cell research communities together with leaders in their respective technology transfer and business communities [42]. Conversely, the SC4SM was born from the top down, growing out of a series of recommendations contained in the "Pattison Report" sponsored by the U.K. government [43]. And, whereas both initiatives are expected to foster commercialization, their philosophies differ sharply owing to the use they have chosen to put stem cells toward. The SC4SM's approach to commercialization is indirect: the initiative is designed to provide a "pre-competitive" space in which stem cells are used as predictive toxicology tools, streamlining the regulatory process for biopharmaceutical firms. In contrast, the CSCC is expected to directly yield a variety of commercial outcomes, including "build[ing] an exciting wave of new biotechnology companies based on CSCC discoveries" from the study of cancer stem cells [44]. Next, the specifics of these two different approaches are spelled out separately and then examined simultaneously under the lens of the anticommons and patent canalyzation.

\subsubsection{Cancer Stem Cell Consortium}

The CSCC was originally conceived as a cross-border research partnership between California and Canada with equal funding from both governments [45], but later shifted to a Canadian-based, -staffed, and -funded initiative [42]. A strong link with Californiabased researchers and institutions was, however, established in June 2008, when the CSCC concluded a three-year agreement with CIRM, the body charged with funding stem cell research in California, to formally explore opportunities for collaboration [46]. The first such opportunity was announced in February 2009, with the release of CIRMs' request for applications for "Disease Team Research Awards" [46].

Before assessing the CSCC's collaborative potential and how the various strings attached to CIRM funding risk complicating the same, it is important to have a basic understanding of how the scientific focus of the CSCC differs from many other stem cell research initiatives. First, whereas hESCs and iPS cells are derived from embryonic and adult tissue sources, so-called "cancer stem cells" are isolated from patient tumor samples. Second, rather than trying to develop stem cells directly into therapies for a variety of degenerative diseases, the CSCC aims to increase our knowledge of the role played by such cells in the mechanism of various forms of cancer, in turn enabling scientists to identify diagnostic, prognostic, and predictive biomarkers to power more effective, "personalized" therapies of the future [44].

By virtue of its focus on cancer stem cells as opposed to the development of stem cell-based therapies, the projects the CSCC seeks to facilitate may avoid many of the "thoroughfares" that Bergman and Graff suggest could be complicated by 
patent hold-up and anticommons issues [24]. Cancer stem cell-related research may, however, have patent thickets of its own to worry about, given the spike in applications of late [45]. The more immediate efficiency concern, discussed below, has to do with how different sources of funding promise to complicate general decision making related to intellectual property. In particular, ownership over any patent rights resulting from CSCC-funded research will be left in the hands of researchers' parent institutions [45]. This sets the CSCC apart from the second model of commercialization under scrutiny here, the SC4SM.

\subsubsection{Stem Cells for Safer Medicines}

The SC4SM, a public-private partnership founded with funding from five different governmental agencies and three multinational biopharmaceutical companies [47, 48], was established in late 2007 with the following objective: to enable the creation of a bank of stem cells, open protocols and standardized systems in stem cell technology that will enable consistent differentiation of stem cells into stable homogenous populations of particular cell types, with physiologically relevant phenotypes suitable for toxicology testing in high throughput platforms [49].

Like the CSCC, then, the SC4SM has no intention of developing stem cell-based therapeutics. Rather, the SC4SM initiative provides an interim, pre-competitive strategy, using stem cells as predictive toxicology tools in an effort to streamline the process of biopharmaceutical development. The SC4SM intends, in other words, to use stem cells to identify what we can call "toxicity biomarkers."

To accomplish this objective, the initiative creates something akin to a club or "protective commons." Entities participating in the initiative are entitled to utilize the intellectual property contributed by other participants as well as any new intellectual property generated as research projects unfold. Entities not participating in the SC4SM may get access to those resources, but they are not entitled to them per se.

To make this work, the SC4SM sets up two categories of intellectual property: "Background IPR" and "Foreground IPR" [50]. While ownership of Background IPR remains with each member of SC4SM, they are obligated to "grant to the [SC4SM] a royalty-free, non-exclusive, perpetual, worldwide and sub-licensable license of its Background IPR solely for the purpose and to the extent necessary for each Project to be undertaken and completed." The SC4SM is, in turn, responsible for sub-licensing such Background IPR to other "participants" in a research project to ensure its successful completion. If any new intellectual property results from the research project, that is, Foreground IPR, then the SC4SM will assume ownership of the same but must grant "a non-exclusive, perpetual, royalty-free, worldwide license" to use such Foreground IPR to each participant in that particular project as well as current members in the SC4SM more generally. Third parties that are external to the initiative may apply for and obtain a non-exclusive license to use such Foreground IPR, but subject to the SC4SM's discretion. In all three instances, Foreground IPR may only be utilized for "research purposes." 
This framework has the potential to generate any number of inefficiencies. As explained next, however, the SC4SM appears to better manage those inefficiencies relative to those likely to be encountered by the CSCC.

\subsubsection{Managing (Potential) Transaction Costs}

A number of definition-related efficiency questions follow from the SC4SM's stated intellectual property policy. According to recent Court decisions, the distinction between "research use" and "commercial use" is increasingly difficult to draw. What exactly, then, does the term "research purposes" as used by the SC4SM encompass? Does it create ambiguity and thus set up future disputes? Moreover, is the distinction between Background IPR and Foreground IPR actually practicable? Or does it, too, suffer from ambiguity in the sense that some Foreground IPR will likely be unusable without access to related Background IPR as in the case of patented improvements?

A closer reading of the SC4SM's intellectual property policy reveals that these issues are, in fact, carefully addressed. While the definitions that delineate the boundary between research use and commercial use are somewhat circular, the distinction drawn is straightforward enough when read in light of the SC4SM's overall objective of fostering more efficient biopharmaceutical development by using stem cells as predictive toxicology tools. The default rule is that anyone holding a license to Foreground IPR cannot commercialize (i.e., sell, develop, dispose of, or authorize another party to do the same) stem cell technologies as predictive toxicology tools, but they can make full use of those technologies in their individual efforts to commercialize new diagnostics, drugs, and biologics. If they wish to undertake "direct exploitation" of Foreground IPR, which presumably includes commercializing some stem cell technology as a predictive toxicology tool, they must apply for a license from the SC4SM to do so. However, in order to ensure that any efficiency gains can be shared with other drug developers in the future, if granted, such a license must be non-exclusive. Similarly, in any situation where a party needs access to Background IPR in conjunction with Foreground IPR - whether in the course of an ongoing research project, to practice the Foreground IPR for research purposes, or, for the purpose of directly exploiting the same - the terms of SC4SM's intellectual property policy provide that such a license will be granted [50].

In this way, the SC4SM would seem to act as a clearinghouse of sorts, at least mitigating transaction costs that research institutions and companies would otherwise incur if access to such intellectual property had to be negotiated on a caseby-case basis. Whether the SC4SM is functioning as intended is not yet known. But an anticommons-type situation appears unlikely to arise, assuming the letter and spirit of the SC4SM's intellectual property policies are followed.

The SC4SM's uniform approach to intellectual property would seem to represent an advantage compared to the CSCC - at least for the time being. To reiterate, the CSCC does not intend to claim ownership over any resulting intellectual property. However, it does intend to play a supportive role as researchers and their parent 
institutions begin to commercialize CSCC-funded research outcomes, specifically, by appointing a number of "Commercialization Officers" with "[cancer stem cell]specific scientific knowledge and relationships with biopharmaceutical companies and investors in the [cancer stem cell] space" to "act as expert advisors and will be dedicated to working with [CSCC] funded researchers and institutions on a project (Research Team) specific basis" [44, p. 15]. Approximately 10\% of the CSCC budget will be devoted to supporting commercialization in this, and presumably other, ways. This is significant. Many of the challenges endured by Canadian research institutions related to commercialization are due to a lack of resources, both financial and human. Nevertheless, the fact that several asymmetries in the laws and policies applicable to Canadian and California researchers and institutions - asymmetries that will be relevant in the context of any collaborative research project funded jointly by the CSCC and CIRM under the newly announced Disease Team Research Award program - remains a major potential problem.

To begin with, there are salient differences between the two jurisdictions surrounding "joint inventorship." The request for applications recognizes this as an issue but fails to state what "specific arrangements as to Joint Intellectual Property" are to be made [46], leaving the issue open for negotiation (and thus potential delay and cost) until a research team comprised of Canadian and Californian scientists is awarded funding, and a situation involving joint inventorship actually arises.

Secondly, CIRM's own intellectual property policies contain a number of provisions that are relatively foreign to typical technology transfer practice (in the USA as well as in Canada). In particular, for-profit applicants for funding are required to provide "plans" to ensure that Californians have affordable access to resulting stem cell technologies [51]. Moreover, all funding recipients must pay back to the State of California a predefined share of net revenues (from licensing and/or product sales) once certain thresholds are surpassed [51, 52]. Rather than clarifying whether and to what extent these and other requirements in force in California apply to Canadian researchers and institutions, CSCC authorities appear to have grafted loosely worded parallel obligations onto their own conditions of funding.

The request for applications, for example, states that the CSCC plans to "reserve March-in rights to ensure that [intellectual property] generated during the course of the project using CSCC funding can be fully exploited for the national benefit," and require that award recipients "provide free access to the Canadian research community to all Publication Related Biomedical Materials generated during the course of the project" [46, p. 29]. While acceptable in principle, the present wording of these stipulations fails to capture several of the nuances built into CIRM's intellectual property regulations around when March-in rights can be invoked, what precisely must be made available to the research community, and when. They are also potentially out of step with policies already applicable to Canadian research institutions in receipt of other funding from other bodies.

True, technology transfer officials are not unaccustomed to multi-institutional, if not also multi-jurisdictional, research initiatives. But that does not mean that research under the umbrella of the CSCC would not benefit from less complex intellectual property architecture. Indeed, efforts are already under way to develop an 
"intellectual property framework," serving as a tool to enable researchers and institutions to identify and work through various intellectual property issues depending on what sources of funding (and corresponding rules and expectations) are involved. ${ }^{5}$ If finalized and followed by recipients of funding from the CSCC, this framework may substantially negate the foregoing inefficiencies. If not finalized (or subsequently followed), the vaguely worded requirements applicable in Canada coupled with the more detailed requirements that govern in California may invite significant delays as technology transfer officials on both sides of the border wade through, interpret, and monitor compliance with the various policies that apply.

\subsubsection{Minimizing (Potential) Costs to Research Quality}

On the other hand, other features of the CSCC's stated approach to commercialization may engender higher quality of research than the SC4SM, at least insofar as patent canalyzation theory holds. Both the CSCC and SC4SM are interested in biomarkers - diagnostic, prognostic, and predictive biomarkers in the context of the former and toxicity biomarkers in the latter. Also noted above, however, is the fact that the clinical validity of most biomarkers identified to date is suspect. There appears to have been a near-systematic failure to ensure that biomarker-disease associations are statistically robust and map onto meaningful clinical outcomes over time [36, 53]. The reasons for this are complex, spanning from gaps and ambiguities in regulatory frameworks, funding deficiencies, to the absence of the necessary large-scale bio-repositories and attendant information management systems [54] - the last of which the CSCC aims to address. But there is arguably also an intellectual property aspect to this quality problem, which I frame as patent canalyzation.

This concern may prove illusory. However, the important point for the time being is that the CSCC appears to be taking a proactive stance. Its architects have clearly recognized the impoverished state of the biomarkers field and, wittingly or not, have taken steps to negate the possibility of patent canalyzation, first by linking its genomics research program to "large-scale cancer resequencing programs such as the NIH-funded project called The Cancer Genome Atlas... project and the International Cancer Genome Consortium" - both of which aim to ensure "rapid and complete" release of data for use by all members of the global research community $[55,56]$; and second, by stressing the importance of linking any identified cancer stem cell biomarkers with "clinical parameters such as patient prognosis and treatment outcome to firmly establish the clinical relevance of [cancer stem cell]s" [44, p. 9]. The CSCC, in other words, allows for experimental replication by independent research teams while at the same time directing the teams that it funds to strive for clinical validation. The CSCC thus

\footnotetext{
${ }^{5}$ Personal communication with Angus Livingstone, Director, University-Industry Liaison Office, University of British Columbia.
} 
promises to enable higher quality research than what would seem to be the status quo for biomarkers.

In contrast, the SC4SM, by seeking to claim Foreground IPR, is following the status quo. Again, this is a speculative concern. Because such newly generated intellectual property will effectively be treated like a club good, perhaps SC4SM partners will help each other with their homework, that is, validate the markers of biopharmaceutical toxicity that they each identify through stem cell modeling. The lack of language to that effect in the SC4SM's mission and policies is, however, somewhat disconcerting.

Given that the initiative is explicitly intended to be precompetitive, the more fundamental question is whether the pursuit of Foreground IPR is at all necessary to achieve its objective of streamlining the process drug discovery. Why not instead make the data available to all members, participants, and third parties via a "clickwrap" license or simply releasing the data into the public domain [57, 58]? Either mechanism would presumably be more cost-efficient than seeking Foreground IPR because it would shed the costs of patent prosecution and any resulting litigation as well as negate the need to review license applications for use of Foreground IPR. Instead, undertaking those (needless) responsibilities takes away from measures similar to those advocated by the CSCC to ensure biomarker quality.

\subsection{Conclusion}

To abstract a set of best practices around intellectual property and collaboration from the two models discussed here potentially obscures the importance of the broader cultural, political, and economic contexts in which any large-scale scientific research initiative is embedded. Three broad points nevertheless follow from the preceding analysis. The first two map primarily onto anticommons concerns whereas the third relates more to this new idea of patent canalyzation. All three should facilitate collaboration in stem cell science.

The first point is that inefficient distribution of all biological materials, not just stem cell lines, has long been recognized as a problem. Encouraging research institutions to adopt a model material transfer agreement has proven insufficient. Architects of research initiatives must therefore seek to make efficient materials exchange a stronger norm within the community of researchers and organizations that choose to participate in the venture. Instead of leaving MTAs to be crafted and negotiated by individual institutions as the need arises, standardized terms and conditions should be set by the initiative at the outset. Distribution of materials according to the same should, in turn, be made a condition of participation in the initiative with failure to do so triggering pre-defined consequences.

Secondly, all scientific research stands to benefit from greater levels of datasharing. The more challenging decision for architects of a large-scale research initiative likely concerns how broadly data will be shared. Due to the perceived risk of "parasitic patenting" [57], several initiatives have opted to make data available 
under click-wrap licenses rather than simply releasing the data into the public domain. Others contend that the risk of parasitic patenting has been exaggerated, and that broader data dissemination is a more immediate concern [58]. Research initiatives should specify a clear policy with respect to data-sharing while continuously re-assessing and balancing the risks of parasitic patenting versus incomplete, inefficient data sharing as research projects under their auspices unfold.

Finally, large-scale initiatives should promote a practice of not patenting "fundamental discoveries." As several commentators have pointed out, and WARF's rigid control of its hESC patented cell lines powerfully illustrates, patenting inventions that are considered foundational to a field of inquiry can hinder research progress. Patenting to ensure that an invention is commercialized, moreover, makes little sense when significant research and development is not required to "bring the invention to practical and commercial application" [59]. Such is the case where fundamental discoveries, especially research tools like cell lines, are concerned. Similarly, architects of large-scale initiatives should consider promoting a practice of not patenting biomarkers of unproven clinical validity, especially in the absence of counteracting measures and resources that promote replication and validation of scientific findings. If not, the vision of patent canalyzation that I articulate here may unfortunately materialize.

\section{References}

1. Matthews DJH, Donovan P, Harris J, Lovell-Badge R, Savulescu J, Faden R. Integrity in international stem cell research collaborations. Science 2006; 313:921-2.

2. Winickoff DE, Saha K, Graff GD. Opening stem cell research and development: A policy proposal for the management of data, intellectual property, and ethics. Yale J Health Policy Law Ethics 2009; 9:52-127.

3. Thomson JA, Itskovitz-Eldor J, Shapiro SS, Waknitz MA, Swiergiel JJ, Marshall VS, Jones JM. Embryonic stem cell lines derived from human blastocysts. Science 1998; 282:1145-7.

4. Walsh JP, Arora A, Cohen WM. Working through the patent problem. Science 2003; 299:1021.

5. Walsh JP, Cohen WM, Cho C. Where excludability matters: Material versus intellectual property in academic biomedical research. Res Policy 2007; 36:1184-203.

6. Caulfield T, Ogbogur U, Murdoch C, Einsiedel E. Patents, commercialization and the Canadian stem cell research community. Regen Med 2008; 3:483-96.

7. ÓConnor, S. The use of MTAs to control commercialization of stem cell diagnostics and therapeutics. Berkeley Technol Law J 2006; 21:1017-54.

8. Lei Z, Juneja R, Wright BD. Patents versus patenting: Implications of intellectual property protection for biological research. Nat Biotechnol 2009; 27:36-40.

9. Yu J, Vodyanik MA, Smuga-Otto K, Antosiewicz-Bourget J, Frane JL, Tian S et al. Induced pluripotent stem cell lines derived from human somatic cells. Science 2007; 318:1917-20.

10. Takahashi K, Tanabe K, Ohnuki M, Narita M, Ichisaka T, Tomoda K et al. Induction of pluripotent stem cells from adult human fibroblasts by defined factors. Cell 2007; 131:861-72.

11. Cyranoski D. Japan fast-tracks stem-cell patent. Nature 2008; 455:269.

12. Vrtovec KT, Scott CT. Patenting pluripotence: The next battle for stem cell intellectual property. Nat Biotechnol 2008; 26:393-5.

13. United States, 37 C.F.R. § 1.52(b)(ii).

14. Stephenson EL, Braude PR, Mason C. International community consensus standard for reporting derivation of human embryonic stem cell lines. Regen Med 2007; 2:349-62. 
15. The Hinxton Group, an International Consortium on Stem Cells, Ethics \& Law. (2006). Transnational Cooperation in Stem Cell Research. http://www.hinxtongroup.org/docs/ Hinxton\%202006\%20consensus\%20document.pdf. Accessed 23 October 2009.

16. Cell Stem Cell, Information for Authors. (2009). http://www.cell.com/cell-stem-cell/authors. Accessed 23 October 2009.

17. Merton RK. Priorities in scientific discovery. Am Sociol Rev 1957; 22:635-59.

18. Eisenberg RS, Rai AK. Harnessing and sharing the benefits of state-sponsored research: Intellectual property rights and data sharing in California's stem cell initiative. Berkeley Technol Law J 2006; 21:1187-214.

19. United States, National Institutes of Health. (2009). Human Embryonic Stem Cell Policy under Former President Bush (August 9, 2001-March 9, 2009). http://stemcells.nih.gov/ policy/2001 policy.htm. Accessed 23 October 2009.

20. United States, Presidential Documents. (2009). Executive Order 13505 of March 9, 2009, Removing Barriers to Responsible Scientific Research Involving Human Stem Cells, 74 Fed. Reg. 10667. http://edocket.access.gpo.gov/2009/pdf/E9-5441.pdf. Accessed 23 October 2009.

21. Wisconsin Alumni Research Foundation. (2007). Wisconsin Alumni Research Foundation Changes Stem Cell Policies to Encourage Greater Academic, Industry Collaboration, WARF NEWS, Jan. 23, 2007. http://www.warf.ws/news/news.jsp?news_id=209. Accessed 23 October 2009.

22. Fitt R. New guidance on the patentability of embryonic stem cell patents in Europe. Nat Biotechnol 2009; 27:338-9.

23. Boman BM, Wicha MS. Cancer stem cells: A step toward the cure. J Clin Oncol 2008; 26:2795-9.

24. Bergman K, Graff GD. The global stem cell patent landscape: Implications for efficient technology transfer and commercial development. Nat Biotechnol 2007; 25:419-24.

25. Heller MA, Eisenberg RS. Can patents deter innovation? The anticommons in biomedical research. Science 1998; 280:698-701.

26. Heller MA. (2008). The gridlock economy: How too much ownership wrecks markets, stops innovation, and costs lives. Philadelphia: Basic Books.

27. United States, National Research Council. (2006). Reaping the benefits of genomic and proteomic research: Intellectual property rights, innovation, and public health. Washington, DC: National Academies Press.

28. Murray F, Stern S. Do formal intellectual property rights hinder the free flow of scientific knowledge? An empirical test of the anti-commons hypothesis. J Econ Behav Organ 2007; 63:648-87.

29. Huang KG, Murray FE (2008). Does patent strategy shape the long-run supply of public knowledge? Evidence from human genetics. Academy of Management Journal, forthcoming. http://fmurray.scripts.mit.edu/docs/Huang.Murray_AMJ_09.16.2008_FINAL.pdf. Accessed 23 October 2009.

30. Mowery DC, Ziedonis AA. Academic patents and material transfer agreements: Substitutes or complements? J Technol Trans 2007; 32:157-72.

31. Waddington CH. (1939). An introduction to modern genetics. New York: Macmillan.

32. Yamanaka S. Elite and stochastic models for induced pluripotent stem cell generation. Nature 2009; 460:49-52.

33. David PA. Clio and the economics of QWERTY. Am Econ Rev 1985; 75:332-7.

34. Ioannidis JP, Gwinn M, Little J, Higgins JP, Bernstein JL, Boffetta P et al. A road map for efficient and reliable human genome epidemiology. Nat Genet 2006; 38:3-5.

35. Hirschhorn JN, Lohmueller K, Byrne E, Hirschhorn K. A comprehensive review of genetic association studies. Genet Med 2002; 4:45-61.

36. Liddell K, Hogarth S, Melzer D, Zimmern RL. Patents as incentives for translational and evaluative research: The case of genetic tests and their improved clinical performance. Intellect Property Q 2008; 3:286-327.

37. Thursby JG, Thursby MC. University licensing. Oxf Rev Econ Pol 2007; 23:620-39.

38. Stuart TE, Ding WW. When do scientists become entrepreneurs? The social structural antecedents of commercial activity in the academic life sciences. Am J Sociol 2006; 112:97-144. 
39. Cosell C, Agrawal A. Have university knowledge flows narrowed? Evidence from patent data. Res Policy 2009; 38:1-13.

40. Bubela T, Strotmann A, Adams R, Morrison S. Commercialization and Collaboration: Competing Policies in Publicly Funded Stem Cell Research? Cell Stem Cell 2010; 7:25-30.

41. Herder M. Patents and the progress of personalized medicine: Biomarkers research as lens. Ann Health Law 2009; 18:187-230.

42. Cancer Stem Cell Consortium. (2008). About Us. http://www.cancerstemcellconsortium.com/ index.php?page $=$ about-us. Accessed 23 October 2009.

43. United Kingdom, UK Stem Cell Initiative. (2005) Report \& Recommendations. http://www. advisorybodies.doh.gov.uk/uksci/uksci-reportnov05.pdf. Accessed 23 October 2009.

44. Cancer Stem Cell Consortium. (2008). Scientific Strategic Plan 2009-2014. http://www. cancerstemcellconsortium.com/uploads/PDFs/CSCC.Full.Str.Plan\%20FINAL \% 20 REVISED\%2018\%20November\%202008_Corrected\%20Date.pdf. Accessed 23 October 2009.

45. Cancer Stem Cell Consortium. (2007). Position paper submitted by John A. Hassell \& Catriona Jamieson. http://www.cancerstemcellconsortium.com/uploads/PDFs/CSC\%20 Consortium\%20May\%2010.pdf. Accessed 23 October 2009.

46. California Institute for Regenerative Medicine. (2009). CIRM Disease Team Research Award. http://www.cirm.ca.gov/RFA/pdf/rfa_09-01/RFA_0901_031009.pdf. Accessed 23 October 2009.

47. Stem Cells for Safer Medicines. (2007). About. http://www.sc4sm.org/about. Accessed 23 October 2009.

48. Stem Cells for Safer Medicines. (2007). Background Briefing. http://www.sc4sm.org/ downloads/SC4SM-QA.pdf. Accessed 23 October 2009.

49. Stem Cells for Safer Medicines. (2007). Welcome to Stem Cells for Safer Medicines. http:// www.sc4sm.org/. Accessed 23 October 2009.

50. Stem Cells for Safer Medicines. (2007). Intellectual Property Rights (IPR) Policy. http://www. sc4sm.org/wp-content/uploads/2007/10/2007-09-sc4sm-ip-policy-final-draft.pdf. Accessed 23 October 2009.

51. California Institute of Regenerative Medicine. (2007). Adopted CIRM Regulations: Chapter 4 - Intellectual Property and Revenue Sharing Requirements for For-Profit Organizations. Cal. Code Regs. tit. 17, § 100400-10. http://www.cirm.ca.gov/reg/default.asp. Accessed 23 October 2009.

52. California Institute of Regenerative Medicine. (2006). Adopted CIRM Regulations: Chapter 3 - Intellectual Property Requirements for Non-Profit Organizations. Cal. Code Regs. tit. 17, $\S$ 100300-10. http://www.cirm.ca.gov/reg/default.asp. Accessed 23 October 2009.

53. Wilson C, Schulz S, Waldman SA. Biomarker development, commercialization, and regulation: Individualization of medicine lost in translation. Clin Pharmacol Ther 2007; 81:153-5.

54. United States, President's Council of Advisors on Science \& Technology. (2008). Priorities for Personalized Medicine. http://www.ostp.gov/galleries/PCAST/pcast_report_v2.pdf. Accessed 23 October 2009.

55. The Cancer Genome Atlas Project. Human Subjects Protection and Data Access Policies. http://cancergenome.nih.gov/objects/pdfs/TCGA_Human_Subjects_prot_\%20policy.pdf. Accessed 23 October 2009.

56. International Cancer Genomics Consortium. (2008). Data Release Policies. http://icgc.org/ icgc_document/policies_and_guidelines/data_release_policies. Accessed 23 October 2009.

57. Gitter DM. Resolving the open source paradox in biotechnology: A proposal for a revised open source policy for publicly funded genomic databases. Houst Law Rev 2007; 43:1475-521.

58. Eisenberg RS. Patents and data-sharing in public science. Ind Corp Change 2006; 15:1013-31.

59. United States, Department of Health and Human Services, National Institutes of Health. (2004). Best Practices for the Licensing of Genomic Inventions, 69 FED. REg. 67747. 